\title{
¿Y Nosotros, Qué?: Moving beyond the Margins in a Community Change Initiative
}

\author{
SANDRA QUIÑONES
}

\author{
NANCY ARES \\ Maryam RazVi Padela
}

MINDY HOPPER

STEPHANIE WEBSTER

University of Rochester

Our ethnography focuses on an urban community change organization within a predominantly African American and Latino population. Latino Critical Race Theory and Critical Race Theory help us understand the Spanish speakers' positioning and how particularities of Latinas/os' experience challenged power relations and group cohesion. Our findings illustrate tensions and contradictions of black-brown communities working in tandem to work against oppression. We argue that manifestations of intergroup conflict negatively influenced the success of this effort. Urban environments are increasingly demographically diverse and understanding how cross-group dynamics are interpreted by traditionally marginalized populations is essential to ensuring the educational, economic, and social success of students. [community change initiative, social context of schooling, Latino Critical Race Theory (LatCrit), Latinos, African Americans]

Since 2006, a comprehensive organization known as the Community for the Children of Lakeview (CCL) aimed to improve the economic, educational, social, and political landscape of children and families who live and work in the northeast area of Lakeview (Ares et al. 2007). CCL was initially created by local school district leaders in response to chronic underperformance of schools and low graduation rates in the Northeast area of Lakeview. The initiative was modeled loosely on the Harlem Children's Zone developed by Geoffrey Canada. Because schools do not exist in a vacuum, the vision of the initiative was to mobilize residents and multiple stakeholders (i.e., social service agencies, nonprofit organizations, churches, business, and government officials) who lived and worked within the surrounding neighborhoods and communities. People working on the planning process of CCL were inspired by their commitment to children and schools and willingness to engage in the development of comprehensive social change. The overarching goal was to improve the educational status of youth and families. Accordingly, three of the eight focus areas identified in the planning stages were education related (i.e., early childhood education, $\mathrm{K}-12$ schools, and adult education).

Given our interest in qualitative inquiry of schools and society, we partnered with the CCL to conduct an ethnography of this urban community change initiative. This article forms part of a series of research papers deriving from the larger Northeast Community Study. The targeted Northeast area has a rich demographic profile that includes a variety of racial and ethnic and social groups, creating a complex and layered history of challenges and resources. Because the residents of the northeast region are predominantly African American and Latina/o, ${ }^{1}$ one of the objectives of the CCL was to engage both African American and Latina/o residents and community leaders in ways that did not perpetuate "business as usual" (see O'Connor et al. [this issue] for extensive analysis of avoiding "business as usual”). However, similar to what Sánchez (2008) and Straus (2009)

Anthropology \& Education Quarterly, Vol. 42, Issue 2, pp.103-120, ISSN 0161-7761, online ISSN 1548-1492. (C) 2011 by the American Anthropological Association. All rights reserved.

DOI:10.1111/j.1548-1492.2011.01119.x. 
found in other studies, despite common interests and civic concerns, positive and sustained coalitions between these two groups have been strained because of competition over various resources (political, financial, educational, occupational). Grounded in this sociocultural and sociopolitical historical context, the CCL aimed to engage African Americans and Latinas/os in transparent and inclusive interactions to promote authentic participation and meaningful community transformation (Chavis 2001; Hernández 2000; Wolff 2001a, 2001b).

Of particular interest to this article are nuances in alliance formation between Latinas/os and African Americans as the initiative unfolded. We utilize race-based theoretical frameworks to understand the dynamics of collaborative community change initiatives. Our research explores how issues of race, language, and power deepen blackbrown tensions and undermine efforts to promote inclusive interactions toward meaningful community collaboration. In our data analysis for this article, we draw from two tenets in Critical Race Theory (CRT) and Latina/o Critical Race Theory (LatCrit). First, racism is endemic to daily life in the United States; it is not rare nor abnormal, and race and racism intersect with other sources of oppression, that is, language, gender, and immigration (Monzó and Rueda 2009; Taylor et al. 2009). Second, many Latina / o communities and individuals engage in strategic resistance to ideologies that perpetuate subordination of Latinos as culturally or linguistically inferior (Solórzano and Delgado Bernal 2001; Yosso 2005; Yosso and García 2007). Our findings include that Latinas/os resisted ideologies and practices that perpetuate assumptions about Latinos being passive and underresourced. Further, they advocated for the unique experiences and resources of their communities to be acknowledged more substantively in the CCL. We show that these moves were met with well intentioned but deficit-based discourses and practices, or benevolent forms of racism (Villenas 2001), and masking of differences, respectively. Overall, our analysis points to how Latina/o participants were marginalized within the initial phases of the organization. Hence, our title, "¿Y nosotros, qué?" or "what about us?" is fitting.

We argue that as a developing social context for schooling, this initiative faced significant obstacles by not attending to divisions between Latina/o and African American communities; those divisions were ignored in favor of presenting a unified front. Further, the various resources each community, particularly Latinas/os, could bring to bear were not recognized. Thus, the prospects for school as well as community transformation were dimmed and ultimately unsuccessful. Given that the CCL was begun with a focus on education and a commitment to designing productive futures for children, we, as educational anthropologists, view the planning process as indicative of complex black-brown dynamics that undermine collaborative community change efforts.

\section{Background Literature}

Historical and political science literature provide insights into the processes of collaboration among racial and ethnic social groups, particularly when the purpose of alliance formation is to counteract racism, inequities and white-dominant structures in multiracial school districts (Meier et al. 2004; Straus 2009) and in large urban cities (Alex-Assensoh and Hanks 2000; Cruz 2000; Falcón 1988; Lee and Díaz 2007; Morales 1986; Sánchez 2008). Two significant themes characterize the literature about African American-Latina/o tensions. One addresses the distinctions in racial consciousness and experiences within the black-white racial landscape of the United States, highlighting the complexity often masked by that racial dichotomy. For example, in a historical account of African American and Puerto Rican coalitions in New York City during the late 1960s and 1970s, Lee and Díaz describe some of the problems that surface when multiple stakeholders from racial and ethnic social groups come together "through a common belief that a coalition would 
strategically serve the interests of both groups" (2007:54). Manny Díaz, an influential Puerto Rican community leader-activist, had to make strategic decisions and build strong relationships and networks to position the Puerto Rican community as allies to civil rights. An important part of this alliance formation and advocacy was to "emphasize that Puerto Ricans' needs as a Spanish-speaking migrant group demanded different pedagogical solutions" (Lee and Díaz 2007:68) aimed toward educational equity (such as bilingual education).

Another theme in the social science literature focuses on the positioning of Latinas/os in the margins of reform efforts. For instance, in a historical account of policies and practices in California's Compton Unified School District, Straus (2009) exposes the struggles between Latinas/os (mostly Chicano or Mexican Americans and Central Americans) and African Americans over education, employment, and overall community empowerment. She demonstrates how racism and discrimination lead to Latinas/os being portrayed as "un-American," revealing competitive nondominant group dynamics that point to the insidious ways that racial and ethnic tensions "emerge when historically disenfranchised groups fight over the scraps of the civic pie" (Straus 2009:528) in the process of demanding access to high quality schools and negotiating control over power and resources in impoverished communities.

Taken together, Straus (2009) and Lee and Díaz (2007) provide historical perspectives of how multiple tensions and power differentials impact collaboration and negotiations between racial social groups in community change efforts, particularly in large urban areas. This study takes this work a step further by utilizing an ethnographic perspective. The resulting depth of understanding afforded by this methodological approach adds to the literature by providing rich and complex descriptions of intergroup relations and interactions, uses of languages, and the evolution of a community transformation process. In addition, we explore the initiative in terms of the kind of social context of schooling it was developing. The analyses we present provide rich detail and therefore can be useful for others pursuing urban school and community transformation as well as black-brown education issues (Dávila and Rodríguez 2000; Hout 2001). Even though "collaboration may be in both groups' mutual interest," our work extends Moll and Ruiz's review of studies that speak to "negative interethnic perception and to potential serious conflict among these and other groups" (2005:314). They note that the latter focus represents an "under-theorized subject of study" (2005:314). Hence, the planning phases of this community-based organization, originally initiated by school district leaders, provided us with a unique opportunity to better understand the social context of schooling and potentially "tell the story" of how multiple stakeholders came together with the goal of changing the educational landscape of children in Lakeview.

\section{CRT-LatCrit as Theoretical Lenses}

Our overarching work focuses on issues of language, power, and race, drawing on CRT and LatCrit to analyze alliances and intergroup relations within the planning phases of the CCL (Elenes and Delgado Bernal 2010; Ladson-Billings 2000). CRT seeks to challenge the ways that race, racism, and dominating power are woven into the fabric of U.S. society (Bell 1992; DeCuir and Dixson 2004; Ladson-Billings 1998, 2000). CRT and LatCrit consider social constructions of race situated in U.S. history and challenge dominant ideologies and white privilege (Solórzano 1997). Both CRT and LatCrit (CRT-LatCrit) are deeply historical race-based theoretical frameworks with origins in legal scholarship (Elenes and Delgado Bernal 2010; Villalpando 2004). Derived from CRT, LatCrit is a progressive, interdisciplinary form of scholarship that "draws from both Chicana/o Studies and the civil rights literature and theoretical bases" (González and Portillos 2007:249). Similar to 
Rolón-Dow, we recognize and value "the close relation between CRT and LatCrit theory and the relevance of both" (2005:88) to the study of Latinos. However, there are key distinctions to note. Specifically, LatCrit extends CRT by emphasizing racial discrimination in a way that includes issues relevant to Latinos, including the role of ethnic discrimination, language rights, immigration, and citizenship (González and Portillos 2007). Within the U.S. context, this has helped center Latinas/os' experiences of language, immigration, gender, ethnicity, transnationalism, and colonization thereby extending the black-white paradigm in studies of race (Rolón-Dow 2005:87).

A limitation of LatCrit scholarship in education is that this body of literature accounts mostly for the experiences of Chicano and Mexican American students and families (Elenes and Delgado Bernal 2010). Elenes and Delgado Bernal point to the need to "address the nuances related to the experiences of other Latinas/os" (2010:72). We contribute to the existing literature by using CRT-LatCrit to center the experiences of Puerto Rican participants in the CCL. The framing of our analysis around a CRT-LatCrit approach gives particular attention to "racialized layers of subordination based on immigration status, sexuality, culture, language, phenotype, accent and surname" (Yosso 2006:6). Three of these concerns-immigration status, phenotype, and language-were prominent for Puerto Rican participants in our data. In the case of immigration, the recent larger sociopolitical context is significant considering anger and suspicion toward immigration, as discussed by Martha Montero-Sieburth and Edwin Meléndez (2007). A critical and timely example is seen in the 2010 Senate Bill 1070 in Arizona requiring that law enforcement officers check documents of people they suspect are in the United States illegally.

Informing this analysis are ties to the complex history of relations among Latina/o and African American communities in Lakeview and more broadly. Accordingly, we were guided by the following questions: (1) How were Spanish speakers positioned during the planning process of the CCL? and (2) How did particularities of the Latina/o experience influence power relations and group cohesion between African American and Latina/o participants within the CCL? Given the broad nature of these questions, an ethnographic approach was warranted.

\section{Lakeview's Latina/o Community Context}

Before presenting our research design and findings, it is important that we situate our study within Lakeview's Latina/o community context. A 2003 census profile of the Latina/o population published by the Center for Governmental Research (CGR) reveals important demographic trends. First, Latinas/os are the fastest growing segment of the population in the county (and particularly in the city of Lakeview). Second, the Latina/o population in Lakeview is predominantly of Puerto Rican descent. Third, the Latina/o population is disproportionately younger (14 or younger) than the population as a whole and Latina/o families are more likely to be headed by a female with children under age 18. Fourth, about 30 percent of Lakeview's Latina/o population indicated that they "do not speak English very well" (CGR 2003:ii). Overall, the CGR (2003) reports that the Latino population in the county "faces challenges with high poverty rates, low home ownership rates, and high rates of single parent households" (iii). Rather than simply taking up the CGR language that is based in a deficit discourse, the realities of the challenges Latinas/os face, along with resources developed in the face of such challenges are important to address together to understand the experiences of the Latina/o community in Lakeview. For this reason, we turned our attention to historical and school district documents that highlight the local social context of schooling.

In a historical account of Lakeview's Puerto Rican community, McCally (2007) highlights how resiliency and endurance, through adaptation and rich family- and community- 
oriented networks, served to counteract a 60-year history of poverty, displacement, and disenfranchisement. This "combination of opportunities and challenges," McCally (2007:5) notes, was instrumental for building the barrio-that is, physical, cultural, and social urban spaces that embody "a network of families, traditions, and institutions" for mutual support (McCally 2007:5). This process of barrio building was not easy and included the need to overcome discrimination and achieve political power in multiple forms and settings. During the 1960s and 1970s, McCally notes that progressive community organizing efforts within the Puerto Rican community were difficult because of structural politics and the reliance on service-oriented approaches to community development. This suggests that our research findings are deeply rooted in longstanding community dynamics.

As far as education, school dropout among Puerto Ricans (and other Latina/os) is a pervasive problem in the Lakeview city school district. Low graduation rates have been a source of concern for over 30 years (AHORA 1986, 1999). To this extent, Lakeview Puerto Rican students, otherwise invisible, become hypervisible in relation to discursive practices around the "graduation rate crisis" or "the problem" to be resolved (Irizarry and AntropGonzález 2007; Nieto 2004; Rodríguez 2008). From a CRT-LatCrit lens, we acknowledge themes that characterize the education of Puerto Ricans, including "the legacy of colonialism; the role of racism, ethnocentrism, and linguicism; and the quest for self-determinism" (Nieto 2004:407). From this perspective, we interrogate how larger structures and practices perpetuate marginalization, neglect, and hopelessness - thereby positioning students (and their respective families and communities) as disposable in a sievelike educational system.

Given the historical demographics and sociopolitical account, we do not characterize Lakeview as a new Latino diaspora settlement area, as described by Wortham and colleagues (2002). Instead, it is a place where long-established populations and the CCL itself were dealing with issues that mirror demographic trends seen in California and New York City, where long-standing African American and Latina/o communities in urban centers are negotiating changes in proportional representation in the political, education, social, and economic landscape (Acosta-Belén and Santiago 2006; González 2000; MonteroSieburth and Meléndez 2007; Straus 2009; Suárez-Orozco and Páez 2002). Thus, what are at play here are shifts in power relations in historically marginalized urban areas and among nondominant groups seeking to improve the educational landscape for the children of Lakeview.

\section{Data Sources}

Our qualitative investigation of our questions utilized a significant data corpus drawn from a larger ethnographic study (Ares et al. 2007; Ares et al. 2008). The first two years of data document the process through which the various CCL work teams and committees created the future goals for the target reform area. Our analysis focuses on several sources from that two-year period (2006-08), including: (1) videotaped stories of becoming aware of one's racialization told by three key Puerto Rican leaders actively involved in the planning process (as members of the Subcommittee and Strategy Teams); (2) an audiotaped, open-ended interview with one of the Latina participants who serves as a representative of the Latina/o community; (3) a videotape of a Strategy Team "Celebration Event" held in February of 2007 to herald the adoption of the CCL Community Plan; (4) key documents generated as part of the planning process; (5) local print media; and (6) 14 videos from Subcommittee and Strategy Team planning meetings. Our data subset also included 42 other documents including field notes, meeting minutes and agendas from Subcommittee and Strategy Team meetings as they provided insights into tensions about race-ethnicity and representation that became an important aspect of the work carried out during meetings and among community leadership. 


\section{Analytic Methods}

Initial codes were developed using a grounded approach to asking of the larger data corpus, "what's going on?" (Charmaz 2006). Prominent codes include "positioning of residents" (ways that residents were involved as central participants as well as how they were "managed"), "control of process versus content" (the ways that the initiative would unfold vs. the goals and objectives that would be the focus), and "collective Other" (identifying each other as people from varied backgrounds who are all subject to shared oppression). It was the tensions and negotiations characterizing the "collective Other" code that lead us to pay specific attention to the particular experiences of Latinas/os and the uses and presence of the Spanish language. For the work reported here, codes specific to our questions about positioning of Latinas / os were subsequently utilized for analysis of all the data sources listed above. Emergent codes across multiple data sources were also identified through memoing during the analysis. For example, the various iterations of the final CCL Community Plan were examined for reference to Latinas/os (e.g., demographic data, historical background of the geographic area), to cultural relevance, and to the Spanish language. Changes in the Community Plan across those iterations were analyzed to discern how the Spanish language and Latinas/os were positioned in relation to the change initiative itself and to other participants in the effort.

For each type of data source, at least three researchers went through a process of independent coding and analytic memoing and then we came together to discuss our findings and draw conclusions. Consensus was achieved through ongoing multiple discussions in research team meetings to establish trustworthiness of our interpretations. Once consensus was reached, researchers coded data independently and created analytic memos from which the findings were written up. This method yielded the multifaceted and nuanced interpretations appropriate to this project by incorporating the interpretations of multiple research team members.

To gather feedback in the form of member reflections (Tracy 2010), two conference papers and an analytic memo that summarized our coding were distributed to participants involved in the Subcommittee. The analytic memo was presented to them during a committee meeting and time was given for them to provide feedback. The most direct confirmation of our interpretations, particularly the experiences and perceptions of the Latinas involved in that committee, came during that meeting. Requests that we continue our exploration of those issues bolstered our sense that our findings, presented next, were trustworthy and confirmable.

\section{Findings}

Our findings are organized around two themes that we found to be predominant across data sources: (1) Spanish language as a resource yet a liability, and (2) masking and dismissing differences for the sake of unity between African American and Latina/o participants (building both a sense of being a collective and challenges to that homogenous collective). We also explore subthemes that add dimensionality to the major themes. Following our analyses of these themes, we discuss them in relation to each other and to our theoretical framework.

\section{Theme: Spanish Language as a Resource Yet a Liability}

Organizers of the CCL stressed the need to "do things differently" to combat the distrust that residents had developed in past years regarding the "powers that be" (see $\mathrm{O}^{\prime}$ Connor et al. this issue). The ordinary way of doing things usually implied that promises 
made would in all probability be broken. According to our data (newspapers, interviews, and videotaped meetings), distrust and disunity had grown in the community over years in response to failed efforts at reform; the community had been positioned as needing to be "fixed" and contentious relations had developed among families and the local school district.

Most importantly, residents felt that previous district initiated programs and other structural changes were forced onto them rather than including resident voice and input. Therefore, CCL's communication strategies sought to increase public trust and demonstrate involvement of multiple racial and ethnic groups, and so, as a result, they varied in audience, method, and intent. Increasing access for Spanish-speaking residents was an important aspect of representing CCL as a novel effort toward coalition building for community change. Its use to both inform and invite was clear across data sources. Video and artifact analyses show that the leadership discussed several strategies for motivating and inviting Spanish-speaking Latina/o residents. Meeting minutes describe numerous instances where explicit plans were made for the translation of documents into Spanish and simultaneous PowerPoint presentations in Spanish. Three distinct subthemes emerged as particularly important: disseminating information, increasing participation, and Spanish speaking being treated as a liability.

Disseminating information. A content analysis of the Communication and Awareness Plan developed by the Subcommittee to publicize the CCL initiative demonstrated efforts to use Spanish as a way to provide Spanish-speaking Latinas/os access to events and activities. Informational materials such as fliers, poster boards, and lapel buttons were generated in English and Spanish. The informational fliers were strategically placed in specific buildings and areas in neighborhoods with large Latina/o populations. Outreach efforts included door-to-door and word-of-mouth communication in neighborhood-gathering places such as community events, neighborhood association meetings, faith-based organizations, and schools. For instance, one Strategy Team member created a list of churches that included "Spanish churches" in an effort to identify target locations for resident recruitment meetings. Another Subcommittee member made copies of the Spanish and English fliers and distributed them at a school with a high Latina/o student population. To further promote recognition, awareness, and engagement, committee members publicized meetings and events on Spanish radio programs and Spanish radio stations.

These efforts to use Spanish as a resource for working to build an inclusive initiative can be seen as related to the LatCrit tenet focused on strategic resistance to ideologies that perpetuate views of Latinas/os as culturally or inherently inferior. In this case, early in the planning stages, not only Latina/o participants pressed for significant involvement from the Latina/o community; other members of the Subcommittee and Strategy Teams also supported this desire for tapping into existing (and valuable) resources in the Latino community toward alliance formation. All seemed to be seeking to be inclusive. As we show, though, those efforts faded as the initiative developed.

Increasing participation. As part of the struggle to improve infrastructure to support bilingual participants, the CCL realized that there was a lack of engagement of the Latina/o community. Therefore, they hired an outreach coordinator named Marie to recruit additional participants. Marie was a native Spanish speaker, familiar with the schools in the CCL region, and according to Latino members of the Strategy Team, known in the Latina/o community. Her work was described by Preston, a member of the Subcommittee Team, in relation to "collaboration with the race piece" (Strategy Team meeting, December 12 , 2006). For him this meant making explicit to participants that the CCL was trying to be inclusive of both Latina/o and black communities. He talked about the teamwork as a 
"Black man and a Latina, and that's a good thing." He went on to talk about outreach teams-Preston and Marie, Glory (an African American woman) and Marie-and argued that they provided a sense of awareness of the "collective piece" in relation to "the race card." This related to efforts to create awareness and to build credibility in the community, partly by making explicit that the CCL recognized that both Black and Latinas/os were important residents of the region. That there was collaboration across groups and entities, specifically around race-ethnicity, was seen by Preston as communicating to the residents that this was an inclusive effort. Yet, this notion that Marie's role served to illustrate a politically savvy, united front was actually problematic because it may not have taken into account the differences in how African Americans and Latinas/os experience and conceptualize racial and ethnic discrimination. The goal of a unified front may have been taken by Latina/o residents and participants as ignoring the particular experiences, resources, and histories of Latinas/os in Lakeview. Indeed, there is some evidence of this perspective, presented below, from videotaped observations and interviews.

Spanish speaking as a liability. The awareness of the need for bilingual (English and Spanish) documents and for conducting outreach activities in target locations speaks to a genuine concern with recruiting and engaging Latino residents. However, our analysis suggests that there was little acknowledgment of or attention to unique concerns that Spanish-speaking populations might have as contributors to the planning process. Instead, Spanish speakers were seen as "in need of a service" and were, at times, segregated from other participants. For example, during work sessions to narrow the number of objectives in the initiative, Spanish-speaking residents were placed together at tables and even labeled as "Spanish only." The word only can be seen as reductionist, portraying the residents as lacking in linguistic capital (Yosso 2005). Even though this grouping may have served practical purposes (fewer interpreters were needed), in effect, it precluded the Spanish-speaking residents from interacting authentically with the rest of the group, as their contributions were included in the resulting information only after such meetings when community-produced content was compiled by the Subcommittee and its staff. Even worse, when it came time to vote for objectives to include in the plan, the "Spanish Only" group was counted as a single vote, while at other tables (Englishspeaking tables), each individual had a vote. This striking move not only positioned the Spanish speakers as "others" but also undermined Latinas/os' political power and value as competent participants with individual voting rights as community residents and members of the CCL.

Moreover, the Spanish translations of documents were provided most often after the texts, policies, and procedures of the initiative had been constructed. The commitment on the parts of the Subcommittee Team and the Strategy Team to have residents control and have ownership of the process and content of the initiative was, therefore, limited because this constructive process was lost to Spanish-speaking residents and their contributions were lost to the process as a whole. Instead, for many Latina/o participants, the work of the Subcommittee was to create awareness for, rather than with them.

Although the organizers noted a strong desire to have ongoing, transparent, and multidirectional communication with resident participants, there was a lack of a working infrastructure to make this possible, particularly for Spanish-speaking residents. In fact, only a small proportion of the planning documents were available in Spanish. Moreover, the CCL website was developed exclusively in English. Again, in the few cases where Spanish was used, it was most often used to disseminate rather than gather information. Inconsistent real-time translation arrangements often made it difficult for Spanishspeaking residents to discuss the matters at hand with their fellow residents during work team meetings and often led to varying degrees of confusion, contrary to the organizers' 
intent. Linguistic differences became a nuisance in terms of time and resources for the organization. Consequently, these situations began to breed tensions among the African American and Latina/o organizers.

Although we recognize that the Latina/o residents' English proficiency may have been a barrier in a setting that privileged business being done in English, what is problematic is that linguistic differences were treated like a problem to be resolved and limited the participants' participation and contribution (Murillo 2002). This approach limited the quantity and quality of the Latina/o participants' interactions with others at the various events. For instance, video analysis of a community celebration unveiling the CCL Community Plan (an event held with residents at a local elementary school auditorium) revealed how three Spanish-speaking participants' involvement began at the periphery (as they hardly talked with others at their own table) and shifted toward central participation when a Spanish interpreter arrived. However, their participation was then shifted back (physically and in terms of contribution) to the periphery when they were displaced to the back corner of the room by the interpreter (see Hopper and Quiñones 2009). As the three participants gathered their materials and began to move to the corner, one of the male participants said, "Nos sacaron, nos botaron" [They've removed us, they've dumped us]. His remark suggests he felt they had been disposed of. Although the move to the corner may have been intended "to help" by minimizing distractions, it was a form of removal that reflected racial prejudices rooted in notions of language. Consequently, the three Spanish-speaking Latinos were not able to fully engage in a discussion of the community plan objectives with the African Americans at the (original) table. This further undermined Spanish speakers' sense of dignity as competent, resourceful, and valuable residentsinstead, they were distinguished as in need of service in the corner of the room where they were relegated to subordinate participation.

As our data reveal thus far, structural practices and approaches to linguistic differences positioned the Spanish-speaking residents in the margins and limited their power and participation. LatCrit scholarship reminds us that these local practices and incidents reflect larger ideologies related to Spanish as a liability and "the stigma associated with the lack of English proficiency in our society" (Monzo and Rueda 2009:20). In effect, endemic racism that is pervasive in U.S. society (and, thus, education; Ladson-Billings and Tate 1995) found its way into the initiative as Latinas/os were positioned as incapable and in need of service. As such, what emerged was a kind of benevolent racism (Villenas 2001) in which well-intentioned but unreflective efforts to be inclusive reified dominant power relations in which Latinas / os were marginalized. In creating a social context for education in Lakeview, such processes and actions of the initiative, when turned to schooling, could lead to "forms of schooling that are not forcibly (and punitively) assimilative, but that deliberately exclude the social cultural or linguistic resources of the students" (Moll and Ruiz 2005:301). This parallels how Spanish is positioned as a liability or inferior in previous studies of schooling (see Flores 2005). In reality and in service of a truly inclusive effort, a "resource rich" view of the Spanish-speaking residents as "holders and creators of knowledge" (Delgado Bernal 2002:105) is necessary for meaningful representation. We argue that this would have been more in line with the CCL's desire to move away from "doing business as usual" (see O'Connor et al. this issue).

In summary, the use of Spanish served multiple purposes, some practical and some strategic. To build on our understanding of the ways that Spanish was and was not used as a resource and to illuminate further the complexity of the issues involving both Latina/o and African American communities, we provide a focused analysis of the tensions that developed in working toward a unified front (a collective Other) and recognizing that African American and Latina/o communities experience oppression in particular ways. 


\section{Theme: (Dis)Unity}

Beyond attempting to address Spanish speakers as part of the initiative, the CCL sought other means to unify and build consensus within a diverse population with a variety of concerns, needs, and resources. There was a strong sense of "moving forward together" in the process versus the risk of perpetuating a fragmented or divisive way of doing things (see Simmons et al. this issue). Most, if not all, meeting documents for both the Subcommittee and the Strategy Teams stated the need to come to a shared understanding of the goals and outcomes of the gathering. In addition, based on our observations, Subcommittee meeting time was often used to discuss personal updates and stories, perhaps to further enhance the diverse and inclusive nature of the CCL as a collaborative community change effort.

Latinas/os advocated for recognition of cultural diversity and for specific attention to the Latina/o community having unique features, experiences, desires, resources, and needs that were being largely ignored, dismissed, or otherwise masked under the excuse that focusing on intergroup differences was divisive and counteractive. Thus, across documents, field notes, videos, and interviews, this theme of unity was clear yet complicated. Three subthemes emerged: (1) framing the Subcommittee and the whole initiative as an effort undertaken by a socially cohesive, collective identity; (2) challenges to unity within the effort and the CCL itself; and (3) masking differences when speaking to power.

Socially cohesive, collective identity. The tension in directly addressing local racial and ethnic difference and division versus avoiding or masking those issues was a key dimension of the theme of unity. We highlight data focused on interactions and dialogue from meetings and events with three Puerto Rican CCL participants-Helena, Norma, and Jesús-to illustrate this point further. For example, Helena, president of a Large Latina/o-serving nonprofit community agency repeatedly advocated for the CCL to address the issue of the vast influx of immigrants and the fact that demographic trends suggest that Latinas/os will be the largest minority group (both locally and nationwide):

I guess the concerns that I had doing this and I mentioned this last time the issue of immigration. ... For me I would say that then African Americans will be fighting with Hispanics for ... like the riots back in the $70 \mathrm{~s}$ or $60 \mathrm{~s} . .$. for money, health care, so that for me that has been a big concern. [interview, October 21, 2008]

Sometimes, as above, the "us vs. them" division was named explicitly. Helena mentioned this in an interview when she said that, "people won't comply because they think it is an African American initiative" (interview, October 21, 2008). In other words, a lack of engagement by the Latina/o residents may have been because of a perception that the CCL was not really for Latinas/os.

At other times, the dismissal was not explicit, nor likely intentional. At the end of the round of stories about racial awareness (see Simmons et al. this issue), Norma, an administrator in the local city school district, asked for an additional turn saying:

can I just say one quick thing though, I had to actually go for some training for a way to help develop my building my self esteem in order to survive in this crazy society, because the more I reflect, I was abused emotionally, because I was forced to go in the cloak room, every time I spoke Spanish by the way, and I would fall asleep on the floor, didn't want to go to school cause who the hell wants to go to school if you can't even sit in the front to learn the damn language. So you know that anger that I had inside me, I really had to go for some, you know, self training and- and try to work those things and it was through many (inaudible) mentors that helped me get to where I am today. [video transcripts, December 4, 2006]

Above, Norma recounted an experience of abuse that was directly related to her use of Spanish in school-being marginalized and isolated, literally forced into a closet as a result 
of speaking Spanish. A few minutes later, Alicia (an African American committee member) described oppressed people as abused and neglected children. In doing so, she drew on Norma's story, acknowledging her experience of abuse, and at the same time, she portrayed this abuse as a general phenomenon, in which members of "minority" groups are "pushed in the closet and treated really bad." In her own words, Alicia said:

I was thinking of our country as the mother of this, of all of us with many children ... that they have something called child abuse and sometime when you have a large family, there's one little child over there that may have been neglected and abused and pushed in the closet and treated really bad, and maybe the parent may not realize all that they're doing to this child.... That's how I look at some, certain minority groups in our country as their abused child, ... We're that abused child. [video transcripts, December 4, 2006]

What is noteworthy is how, for Alicia, the experience of neglect and abuse, of being "pushed in the closet and treated really bad" was not, as it was for Norma, distinctively grounded in language. Norma's experience of rejection of her language as a Latina speaker of Spanish was erased. We can see the tension in a push to claim solidarity as a "collective Other"- "we're that abused child" - that shares experiences of oppression versus we are a diverse group of people who experience oppression differently based on the focus of abuse (Ares et al. 2007).

From a CRT-LatCrit perspective, this stripping away of language and replacing it with a discourse of "minority" as abused child can be seen as an instance of a "stock story" being invoked to mask difference and division (see Delgado and Stefancic 2001; RolónDow 2005). As a social context for education, this atmosphere of avoidance or denigration of relations among language, race-ethnicity, and racism served to lay a shaky foundation for Latinas/os, one that may well perpetuate a lack of sufficient responsiveness by schools to their unique resources and challenges.

Masking difference when speaking to power. The push to acknowledge heterogeneity within the CCL was met with resistance. Moses, an African American male, responded to Helena's request for a collective public statement that proclaimed that the Latina/o and African American communities were moving forward together by saying that he saw the issue as "entirely different" because his experience told him that "the powers that be" [the dominant white power structures] saw "minorities" as the problem. He then stated, "that minority that they're looking at are you [as Latina] and I [as African American]" and that he had a real problem with "my side of the fence vs. your side of the fence" discursive practices. Moses continued to say:

I've been where people have said, no no I don't care whether you speak Spanish, I don't care whether you speak Ethiopian, I don't care whether you speak anything, you're going, alright. ... If we lose perspective of who we are and that we're in the same boiling pot together, you know, if we're all boiling together you're on the left and I'm on the right doesn't make a difference, we're all going to die! [video transcripts, December 4, 2006]

Moses's comment highlights the notion of "shared oppressions" and sense of urgency toward a collective effort to counteract racism and other forms of subjugation. In fact, Moses voiced an explicit challenge to naming heterogeneity, arguing that they must fight together or they will die together. He moved away from the issue of competing for resources or having to recognize differences in the community that impact CCL objectives and priorities related to the community plan.

Additional data sources and events include this call to present a unified front against institutional and historical racism that is directed at "Others," but add to our understanding by naming white privilege and "speaking to power" specifically. For instance, Roger 
(African American) and Julie (white) made this move when they advocated taking out reference to race-ethnicity and immigrant status in the final Community Plan:

Julie says that from a political standpoint, it is most difficult to talk about race. Because the power structure of the city is made up of approximately 12 white men who have power over areas like city hall and the school district. It may not be in the best interest of the CCL to speak the truth at this point. Because of this, Roger sides with the point made by Julie earlier to steer away from such racial targeting of us vs. them. Roger says that it is more important to build racial consciousness and acknowledge that people have not been fully accepted in society (i.e. because of race, status, etc.) and use that message to move forward. [field notes, December 4, 2006]

The desire to present a united, homogeneous front was borne of a perceived need to marshal a collective voice in confronting entrenched power, power exerted by monied, white men. The discourse about the initiative representing a collection of diverse, racialized peoples representing varied cultural and linguistic communities was seen as dangerous in that it could be dismissed, especially if internal divisions were acknowledged. Still, during a later subcommittee meeting, Jesús, a community organizer and advocate, pushed back against the move to collective Other:

Jesús: Don't you guys ever ever think that this has been completely, completely taken by the whole community.

Julie: Oh no no no

Derrick: Ooh

Jesús: So we gotta understand that it's not completely com-

Helena: Embraced

Jesús: ah eh you know, embraced by the whole community. You know what I'm saying ... [video transcripts, February 2, 2007]

Thus, beyond differences in the experiences, backgrounds, histories, and resources of the Latina/o and African American communities involved in the CCL, Jesús and Helena named the unresolved political divisions that accompanied the initiative (Ares et al. 2007). These moves to acknowledge both the particularities of the Latina/o experience and community, along with the history and recent relations between African Americans and Latinas/os, complicated the CCL's efforts to operate in relation to institutions, structures, and people in power, given that they wanted to provide a unified or collective front to confront oppression while, for some, also taking into account the heterogeneity within the CCL communities.

Moves to a collective "Other" worked in tension with the Latinas' explicit references to features of Latina/o experiences that make them distinct from others', that they make up an important part of the CCL community, and that should, they argued, shape the CCL initiative in particular ways. The desire on the parts of Latinas/os was to be recognized explicitly as a community with particular experiences, histories, interests, political and social positioning, needs, and resources. As a result of the positioning of Spanish speaking being a liability and Latina/o-specific experiences of oppression being dismissed, Latinas/os were put in the position of having to resist both white privilege and African Americans being positioned as more politically powerful than Latinos in the CCL. Similar to Villenas's (2001:9) observation that, for the Latina mothers in her study, "benevolent racism ... was the normalization of white/Western middle-class cultural ways," in CCL the normalization was of English as the language of the initiative and white privilege (money and power) as the dominant paradigm against which a unified front was necessary.

In summary, the themes we identified provide a multidimensional view of the ways our two central themes-Spanish as a linguistic resource, yet a liability; and masking differ- 
ences for the sake of unity-illuminate the complexities of the CCL initiative. Our findings-particularly around unity, diversity, and group cohesion-speak to challenges in alliance building among African American and Latino participants seeking authentic participation and meaningful transformation through this community change initiative. Good intentions and targeted efforts combined with competing agendas, lack of understanding of particularities of Latina/os' experiences and resources, and the pressure of providing a united front to the "powers that be" effectively kept the Latina/o community from being central participants in this community change initiative. For an initiative whose origin was in schools, whose core value was that all the efforts were "for the children," and whose goal was to provide a context for successful learning and development, the positioning of Latinas/o students and their families at the margins could very easily translate into maintenance of current inequities. These inequities revolve around assimilative and subtractive school practices (Valenzuela 1999).

\section{Discussion}

Our ethnographic approach to this community transformation initiative yields a rich understanding by uncovering tensions, contradictions, and possibilities of black-brown communities working in tandem to design a productive social context of education for children. At stake is how African Americans and Latinas/os "continue to experience, respond to and resist racism and other forms of oppression" (Yosso 2005:72). Given that speaking Spanish was treated more like a cultural liability to be dealt with rather than a cultural asset to draw on, we were drawn to Monzó and Rueda's question:

How then can Latina/o students [and adults] preserve a sense of dignity as Spanish speakers in an English speaking world? That is, how can they present themselves as competent, intelligent, resourceful and valuable when so many interactions they engage in with the outside world render them incapable, limited, underprepared, victims of cultural deprivation? [2009:22]

Admittedly, our study begins to scratch the surface in accounting for some of the pressing issues facing Puerto Ricans (and other Latinas/os) as they participate in community change initiatives to ameliorate toxic social contexts of schooling for children and youth. Our work speaks to resisting ideologies that devalue language and culture and that privilege monolingual English ways of "doing things," a salient theme in LatCrit literature (Delgado Bernal and Villalpando 2002; Villalpando 2004). Furthermore, our findings demonstrate that an unintended consequence of benevolent racism and denial of divisions for the sake of unity led to Latinos being positioned at the margins and operating as "outsiders" (Urciuoli 1996).

Our analyses uncover nuances in the ways that participants negotiated the tensions of working as a "collective Other" that have experienced shared oppressions at the same time as they, especially the Latina/o participants, worked to claim a particular experience bound up with being Spanish speakers, immigrants, and operating within cultural norms that differed from their African American collaborators. Broadly speaking, our study illuminates challenges in cross-racial alliance formation, particularly in efforts to form a "collective Other" to create transformative community change (Chavis 2001; Lee and Díaz 2007). Rather than "a simple call for 'minority' rights or a common 'white' enemy" (Lee and Díaz 2007:73), the CCL "needed to understand how racism worked differently among their particular communities, and how they themselves perpetuated racist patterns of thought with one another" (Lee and Díaz 2007:73).

Smith (2002) and other urban ethnographers recognize that "disparities in relations of power" are persistent and insidious issues in education (Moll and Ruiz 2005:295). Essen- 
tially, what Lakeview's Latina/o and African American participants seek is educational sovereignty. Moll and Ruiz use this to term "to capture the need to challenge the arbitrary authority of 'white' power structures and re-establish within the Latina/o [and African American] communities themselves the structures and norms by which to determine the essence of education for Latinos (and other minority) students" (2005:296). In using this term, Moll and Ruiz are not advocating for acts of separation but, rather, "developing strategic social networks to create 'cultural spaces' that will enhance the autonomy, mediate ideological and programmatic constraints, and provide additive forms of schooling" (2005:300) for students and their surrounding communities. For Latinas/os "educational sovereignty also means reclaiming their language rights, in the midst of their oppression, and the aggression perpetrated by the dominant society" (Moll and Ruiz 2005:300). Our findings suggest how, in order to work toward educational sovereignty, Latinas / os in the CCL had to simultaneously resist both (local and global) white and black power structures.

\section{When the Field Parallels the Theoretical Ground}

Black-brown collaborative efforts toward educational sovereignty in minority-majority communities need to "acknowledge the multiple strengths of Communities of Color in order to serve a larger purpose of struggle toward social and racial justice" (Yosso 2005:69). This is a challenging task for all of those involved. Nonetheless, our grounding in CRT-LatCrit allows us to avoid simplistic descriptions of the ways that race, language, and power circulated in this community change initiative. Instead, we work to provide a multidimensional view that embraces complexity and can serve as important information that the participants can (and have) act(ed) on.

Although nondominant populations tend to be marginalized in society as a whole, there is a trend toward staggered power relations within those marginalized communities as well (Lee and Díaz 2007; Meier et al. 2004; Straus 2009). In some ways, what we saw "play out" between African Americans and Latina/o participants in the CCL parallels the complex interrelationship between theory and practice in CRT and LatCrit. Both theoretical frameworks share basic assumptions about the centrality of race in the United States and the need to counteract systemic and institutional forms of racial subordination. Additionally, both theories are "informed by the experiential knowledge of marginalized communities" (Elenes and Delgado Bernal 2010:63). However, LatCrit scholars (symbolically) asked, "what about us" to suggest that the black-white binary "did not allow the intersections of race, class, gender, sexuality, language, immigration status, and other important issues related to Latinas/os to be sufficiently addressed" (Elenes and Delgado Bernal 2010:65). For our own work, we find that LatCrit is a powerful framework because it highlights commonalities that speak to the broader Latina/o experience represented in the CCL. It allows us to go beyond the black-white binary that is often examined to center the cultural assets and resources of Latino communities (Martinez 2007), thereby affirming the Spanish language and cultural resources of the Latina/o community and unveiling resilience against racism and the dominant culture, while attending explicitly to issues of power (Bourdieu and Passeron 1977; Yosso 2006).

However, we are not suggesting that LatCrit and CRT, or in this case, the Latino and African American communities involved in community change efforts, are incompatible or inherently in competition with each other. Rather, we recognize that LatCrit allowed us to ask certain questions of the data and frame the analysis in ways that speak more directly and authentically to the Latina/o participants. To this extent, our findings are symbolic of a kind of theoretical praxis that mimics the challenges and nuances of cross-racial alliances in liberatory discourses (Elenes and Delgado Bernal 2010; Ladson-Billings 2000). 


\section{Conclusions and Implications}

As collaborative ethnographers, we recognize that there is danger in examining within-community tensions. Addressing the inevitable struggles for position within oppressed communities can overwhelm attention to the complexity of the negotiations and the institutional racism that such collective efforts strive to overcome. It can distract attention from the truly oppressive relations among dominant-nondominant groups that efforts such as this seek to attack. In essence, our own fears mirror those of the CCL participants.

Although the CCL is to be commended for its bold plan and ambition, this article yields some cautionary points that may assist like-minded organizations to carry out future efforts in a more strategic fashion. As ethnographers with sincere interest in the well-being of the target area and population, we hope that our work will serve to build more viable and authentic strategies for current and future community-based change initiatives. Further analysis needs to continue to unpack differing communication and interaction patterns, and our responsibility as critical ethnographers is to work with the CCL community and account for cultural relevance or the lack of it, so that the resources (cultural, political, social, linguistic) Latina/os bring to future efforts are welcomed and can add in important ways to the pursuit of the goals of such work. We hope that our work contributes to improved collaborative social change efforts so that the question " $i y$ nosotros, qué?" is not only taken up in a substantive manner, but is also reframed in a way that acknowledges both the shared oppressions and the unique resources and resiliency the various communities involved bring to bear.

\section{Notes}

Acknowledgments. We thank the members of the CCL Subcommittee and participants in the CCL as a whole for generously granting extensive access to their planning meetings. We also thank Kris Gutiérrez and members of the CCL research team for commentary on previous drafts of this article, and Nancy Hornberger and four anonymous reviewers for their extensive and helpful reviews. The research on which this article was based was supported by a grant from the Margaret Warner Graduate School of Education and Human Development.

1. The word Latina/o or Hispanic describes a heterogeneous ethnic group, not a monolithic group. Latina/os may self-identify as Mexican or Mexican American, Chicano, Puerto Rican, Dominican, Cuban, Central American, South American, and so forth. According to Guadalupe San Miguel Jr. and Rubén Donato the term Latino is used "as an umbrella group for several nationality groups whose country of origin is in the Spanish-speaking countries of Mexico, Central America, the Caribbean, and South America" (2010:27). Accordingly, we recognize that "the literature generally refers to the history and educational experiences of mostly Mexicans, and, to some extent, Puerto Ricans." We choose to use the term Latina/o to account for gendered experiences of individuals.

2. Italicized type indicates increased emphasis in speaking.

\section{References Cited}

Acosta-Belen, Edna, and Carlos Enrique Santiago

2006 Puerto Ricans in the United States: A Contemporary Portrait. Boulder, CO: Lynn Rienner. AHORA Report

1986 Hispanic Studies Project. Rochester, NY: Rochester City School District. 1999 Hispanic Studies Project. Rochester, NY: Rochester City School District.

Alex-Assensoh, Yvette M., and Lawrence J. Hanks, eds.

2000 Black and Multiracial Politics in America. New York: New York University Press.

Ares, Nancy, Joanne Larson, and Kevin O'Connor

2008 Opening the Black Box: Transformative Potential of School/Community Relationships in a Collaborative Urban Change Initiative. Paper presented at the Annual Meeting of the American Educational Research Association, New York, March 25. 
Ares, Nancy, Joanne Larson, Kevin C. O'Connor, and Jana Carlisle

2007 Getting Started: First Stages of Community Reform. Paper presented at the Annual Meeting of the American Educational Research Association, Chicago, April 13.

Bell, Derrick A.

1992 Faces at the Bottom of the Well: The Permanence of Racism. New York: Basic.

Bourdieu, Pierre, and Jean Claude Passeron

1977 Reproduction in Education, Society, and Culture. London: Sage.

Center for Governmental Research (CGR)

2003 Profile of the Hispanic/Latino Population in Monroe County 1970-2000; 2003 Update.

Prepared for Ibero-American Action League. Rochester, NY: CGR.

Charmaz, Kathy

2006 Constructing Grounded Theory. A Practical Guide through Qualitative Analysis. Thousand Oaks, CA: Sage.

Chavis, Davis M.

2001 The Paradoxes and Promise of Community Coalitions. American Journal of Community Psychology 29(2):309-320.

Cruz, José E.

2000 Interminority Relations in Urban Settings: Lessons from the Black-Puerto Rican Experience. In Black and Multiracial Politics in America. Yvette M. Alex-Assensoh and Lawrence J. Hanks, eds. Pp. 84-112. New York: New York University Press.

Dávila, Rosa, and Nestor Rodríguez

2000 Success and Challenges of Relations between African Americans and Latinos. In Beyond Racism: Embracing an Interdependent Future. Lynn Huntley, ed. Pp. 36-48. Atlanta: Southern Education Foundation.

DeCuir, Jessica T., and Adrienne D. Dixson

2004 "So When It Comes Out, They Aren't That Surprised That It Is There": Using Critical Race Theory as a Tool of Analysis of Race and Racism in Education. Theme issue, "Disciplinary Knowledge and Quality Education," Educational Researcher 33(5):26-31.

Delgado, Richard, and Jean Stefancic

2001 Critical Race Theory: An Introduction. New York: New York University Press.

Delgado Bernal, Dolores

2002 Critical Race Theory, Latino Critical Race Theory, and Critical Raced-Gendered Epistemologies: Recognizing Students of Color as Holders and Creators of Knowledge. Qualitative Inquiry 8(1):105-126.

Delgado Bernal, D., and O. Villalpando

2002 An Apartheid of Knowledge in Academia: The Struggle Over Knowledge in Academia: The Struggle Over the "Legitimate" Knowledge of Faculty of Color. Equity and Excellence in Education 35(2):169-180.

Elenes, C. Alejandra, and Dolores Delgado Bernal

2010 Latina/o Education and the Reciprocal Relationship between Theory and Practice. Four Theories Informed by the Experiential Knowledge of Marginalized Communities. In Handbook of Latinos and Education: Theory, Research, and Practice. Enrique G. Murillo Jr., Sofia A. Villenas, Ruth Trinidad Galván, Juan Sánchez Muñoz, Corinne Martínez, and Margarita Machado-Casas, eds. Pp. 63-89. New York: Routledge.

Falcón, Angelo

1988 Black and Latino Politics in New York City: Race and Ethnicity in a Changing Urban Context. In Latinos in the Political System. F. Chris Garcia, ed. Pp. 171-194. Notre Dame, IN: University of Notre Dame Press.

Flores, Barbara M.

2005 The Intellectual Presence of the Deficit View of Spanish-Speaking Children in the Educational Literature during the 20th Century. In Latino Education: An Agenda for Community Action Research. Pedro Pedraza and Melissa Rivera, eds. Pp. 75-98. Mahwah, NJ: Erlbaum.

González, Juan

2000 Harvest of Empire: A History of Latinos in America. New York: Viking.

González, Juan Carlos, and Edwardo L. Portillos

2007 The Undereducation and Overcriminalization of U.S. Latinas/os: A Post-Los Angeles Riots LatCrit Analysis. Educational Studies 42(3):247-266.

Hernández, Antonia

2000 A Framework for Good Intergroup Relations in the United States. The African American and Latino Case. In Beyond Racism: Embracing an Interdependent Future. Lynn Huntley, ed. Pp. 49-57. Atlanta: Southern Education Foundation. 
Hopper, Melinda, and Sandra Quiñones

2009 Entre la Silla y la Esquina. Co-Constructing Meanings from Nonverbal and Verbal Interactions in Video Data Analysis. Paper presented at the Annual Meeting of the American Education Studies Association, Pittsburg, PA, November 5.

Hout, Michael

2001 Educational Progress for African Americans and Latinos and the United States from the 1950s to the 1990s: The Interaction of Ancestry and Class. Working paper. Berkeley: Survey Research Center, University of California.

Irizarry, Jason G., and Rene Antrop-González

2007 RicanStructing the Discourse and Promoting School Success: Extending a Theory of Culturally Responsive Pedagogy for DiaspoRicans. Centro Journal 19(2):37-59.

Ladson-Billings, Gloria

1998 Just What Is Critical Race Theory and What's It Doing in a Nice Field Like Education? International Journal of Qualitative Studies in Education 1:7-24.

2000 Racialized Discourses and Ethnic Epistemologies. In Handbook of Qualitative Research. 2nd edition. Norman K. Denzin and Yvonne S. Lincoln, eds. Pp. 257-277. Thousand Oaks, CA: Sage.

Ladson-Billings, Gloria, and William F. Tate

1995 Toward a Critical Race Theory of Education. Teacher College Record 97(1):47-68.

Lee, Sonia S., and Ande Díaz

2007 "I Was the One Percenter": Manny Díaz and the Beginnings of a Black-Puerto Rican Coalition. Journal of American Ethnic History 26(3):52-80.

Martinez, Elizabeth

2007 Seeing More Than Black and White. In Race, Class and Gender: An Anthology. 6th edition. Margaret L. Anderson and Patricia Hill Collins, eds. Pp. 105-111. Belmont, CA: ThomsonWadsworth.

McCally, Karen

2007 Building the Barrio: A Story of Rochester's Puerto Rican Pioneers. Rochester History 70(2):124.

Meier, Kenneth J., Paula D. McClain, J. L. Polinard, and Robert D. Wrinkle

2004 Divided or Together? Conflict and Cooperation between African Americans and Latinos. Political Science Quarterly 57(3):399-409.

Moll, Luis, and Richard Ruiz

2005 The Educational Sovereignty of Latina/o Students in the United States. In Latino Education: An Agenda for Community Action Research. Pp. 295-320. Mahwah, NJ: Erlbaum.

Montero-Sieburth, Martha, and Edwin Meléndez, eds.

2007 Latinos in a Changing Society. Westport, CT: Praeger.

Monzó, Lilia D., and Robert Rueda

2009 Passing for English Fluent: Latino Immigrant Children Masking Language Proficiency. Anthropology and Education Quarterly 40(1):20-40.

Morales, Julio

1986 Puerto Rican Poverty and Migration: We Just Had to Try Elsewhere. New York: Praeger.

Murillo, Enrique G., Jr.

2002 How Does It Feel to Be a Problem? "Disciplining" the Transnational Subject in the American South. In Education in the New Latino Diaspora: Policy and the Politics of Identity. Stanton Wortham, Enrique G. Murillo, Jr., and Edmund T. Hamann, eds. Pp. 215-240. Westport, CT: Ablex.

Nieto, Sonia

2004 A History of the Education of Puerto Rican Students in U.S. Mainland Schools: "Losers," "Outsiders," or "Leaders"? In Handbook of Research on Multicultural Education. 2nd edition. James A. Banks and Cherry A. McGee Banks, eds. Pp. 388-411. San Francisco, CA: Jossey Bass.

Rodríguez, Louis F.

2008 Latinos School Dropout and Popular Culture: Envisioning Solutions to a Pervasive Problem. Journal of Latinos and Education 7(3):258-264.

Rolón-Dow, Rosalie

2005 Critical Care: A Color(Full) Analysis of Care Narratives in the Schooling Experiences of Puerto Rican Girls. American Educational Research Journal 42(1):77-111.

San Miguel, Jr., Guadalupe, and Rubén Donato

2010 Latino Education in Twentieth-Century America: A Brief History. In Handbook of Latinos and Education: Theory, Research, and Practice. Enrique G. Murillo Jr., Sofia A. Villenas, Ruth 
Trinidad Galván, Juan Sánchez Muñoz, Corinne Martínez, and Margarita Machado-Casas, eds. Pp. 27-62. New York: Routledge.

Sánchez, Gabriel R.

2008 Latino Group Consciousness and Perceptions of Commonality with African Americans. Social Science Quarterly 89(2):428-444.

Smith, David

2002 The Challenge of Urban Ethnography. In Ethnography and Schools: Qualitative Approaches to the Study of Education. Enrique Trueba and Y. Zou, eds. Pp. 369-387. Lanham, MD: Rowman and Littlefield.

Solórzano, Daniel G.

1997 Images and Words That Wound: Critical Race Theory, Racial Stereotyping and Teacher Education. Teacher Education Quarterly 24:5-19.

Solórzano, Daniel G., and Dolores Delgado Bernal

2001 Examining Transformational Resistance through a Critical Race and LatCrit Theory Framework: Chicana and Chicano Students in an Urban Context. Urban Education 36(3):308-342.

Straus, Emily E.

2009 Unequal Pieces of a Shrinking Pie: The Struggle between African Americans and Latinos over Education, Employment, and Empowerment in Compton, California. History of Education Quarterly 49(4):507-529.

Suárez-Orozco, Marcelo M., and Mariela M. Páez, eds.

2002 Latinos: Remaking America. Berkeley: University of California Press.

Taylor, Edward, David Gillborn, and Gloria Ladson-Billings

2009 Foundations of Critical Race Theory in Education. New York: Routledge.

Tracy, Sarah J.

2010 Qualitative Quality: Eight "Big Tent" Criteria for Excellent Qualitative Research. Qualitative Inquiry 16(10):837-851.

Urciuoli, Bonnie

1996 Exposing Prejudice: Puerto Rican Experiences of Language, Race, and Class. Boulder, CO: Westview Press.

Valenzuela, Angela

1999 Subtractive Schooling: U.S.-Mexican Youth and the Politics of Caring. New York: State University of New York Press.

Villalpando, Octavio

2004 Practical Considerations of Critical Race Theory and Latino Critical Race Theory for Latino College Students. New Directions for Student Services 105:41-50.

Villenas, Sofia

2001 Latina Mothers and Small-Town Racisms: Creating Narratives of Dignity and Moral Education in North Carolina. Anthropology and Education Quarterly 32(1):3-28.

Wolff, Thomas

2001a Community Coalition Building-Contemporary Practice and Research: Introduction. American Journal of Community Psychology 29(2):165-172.

2001b The Future of Community Coalition Building. American Journal of Community Psychology 29(2):263-268.

Wortham, Stanton, Enrique Murillo Jr., and Edmund Hamann, eds.

2002 Education in the New Latino Diaspora: Policy and the Politics of Identity. Westport, CA: Ablex.

Yosso, Tara J.

2005 Whose Culture Has Capital? A CRT Discussion of Community Cultural Wealth. Race Ethnicity and Education 8(1):69-91.

2006 Critical Race Counterstories along the Chicana/Chicano Educational Pipeline. New York: Routledge.

Yosso, Tara J., and David G. García

2007 "This is No Slum!": A Critical Race Theory Analysis of Community Cultural Wealth in Culture Clash's Chavez Ravine. Aztlan: A Journal of Chicano Studies 32(1):145-179. 